\title{
Ethological methods for growing bulls and stimulating their sexual function
}

\section{Kozyr V. ${ }^{1}$, Barabash V. ${ }^{2}$}

SE «Institute of cereal crops of NAAS», Volodymyr Vernadskyi Str., 14, Dnipro, 49027, Ukraine; e-mail: 1, 2izkzoo3337@gmail.com

The purpose. To determine ethological methods for growing bulls and stimulating their sexual function. Methods. Method of groups-analogues under equal conditions of growing, feeding and use of producers; ethological methods of study of behaviour of animals in herd and mini-herd; zoo-technical and statistical. Results. It is proved that sexual function and quality of bulls' sperm can be raised due to mechanopressure and electrostimulation of their erogenous zones. Conclusions. Limitation of intersexual selection at bulls is possible at lowering stressful situation. Sexual dynamical stereotype develops at gobies on the basis of imprinting after the first delivery of sperm in artificial vagina. The designed methods and devices for electrostimulation by sinusoidal modulated currents and mechanopressure of erogenous acupuncture zones can restore libido and erection at bulls.

Key words: bulls, growing, exercise, stimulation, sperm.

\section{https://doi.org/10.31073/agrovisnyk201806-06}

Most companies practice group bulk culling, especially during their monitoring. They jump on each other, sometimes injured and contribute to anonymity, resulting in the resulting sperm on an artificial vagina does not fully meet the standard requirements [1,2].

The limitation of intersexual selection and elimination of the causes of increased sexual reactions and the decrease in the quality of sperm production requires a special system for the formation of technological groups of bulls $[3,4,5]$. Therefore, research on the ethological, justified priority method of culling is of relevance.

Material and methods of research. The long-term research and testing (implementation) of the results was carried out in the breeding enterprises and agribusinesses of Ukraine (Crimean, Volyn, Drogobych, Sumy, Dnipropetrovsk breeding associations, IBCRUAAN), Tajikistan (APO "Khoveling", Tajik NUT) with a population of more than 1400 bulls-fruit growers and 1 thousand of bulls on fattening of different breeds and age. The main methods of research were the method of group-analogues under the same conditions of retention, feeding and use, ethological methods for studying the behavior of animals in the herd and miniherd, "zootechnical and statistical [6]. Groups of pedigrees were formed taking into account the width of their breasts for shoulder blades [7].

Research results. The constant finding of the bogs near the same individuals and the lack of the ability to run on the inevitable or hop on each other during a motility in the ring corridor significantly reduced the stressful situation among the animals, positively influenced their sperm production [8]. This made it possible to prevent overexertion of the body of the bulls, to improve their sperm production and to accelerate the extinction of sexual and defensive reflexes on the pedigree, which goes forward during the motion.

Due to this, the bug-neighbors stopped responding to each other sexually and defensively. At the same time, the extinction of sexual reflexes on the rest of the group of boars, with which each of them did not contact with such maintenance, was eliminated. This contributed to the constant support of high-level libido at the intake of sperm in the manage [9].

Effectiveness of mediated (in the form of other bulls) training technological conditional sexual reflexes showed that only $7(7.5 \%)$ of the 7 boogers of the first group were trained to sperm on the artificial vagina on the first day. The rest of the bulls could not be taught. At the same time it took an average of 24 minutes to study one bull. Work on training was associated with great physical strain of the pastoralist. 
To evaluate the effectiveness of individual training, the following procedure the capture remained the same, and the place of capture was changed. In the second capture, sperm was managed to receive from $71.9 \%$ of the bulls in the first group, or $14.8 \%$ more than after the first taking. It took 50 seconds for training. For the third taking all the bulls of the first group were trained in the semen of the artificial vagina.

For the first time, the bulls of the second group (also 7 goals) were taken immediately after imitating the taking process. Due to indirect training, already at the first take, sperm was obtained from $5(71.4 \%)$ bulls and lost 3 times less time and labor. During the second take, all the bulls of the second group already learned to sperm out.

Consequently, mediated learning is the most effective way the commissioning of young bulls, as in practice on the training future breeders to sperm injection spends a lot of time [10,11].

Indirect training of bulls for sperm injection on mechanical installation took place in three stages. At the first stage of the training, the animals were alternately brought to a hook in a machine gun. If simultaneously trained 3-4 bulls, then the results improved due to the mutual stimulation of the libido and the manifestation of the reflex of the active impression memorization (imprinting).

At the second stage, the mechanical installation was arranged directly in the machine at the place where the standing animal was previously standing. Indirect training was conducted both individually and in a group way. Of the 18 boogies, when studying in a group way on the first day, sperm was taken at $17.7 \%$; the second $-81.2 \%$ and the third $-87.5 \%$ of animals. At the third stage, acquired skills of animals were fixed.

Ethological studies have found that the capture of sperm in the bulls should be carried out quickly and immediately removed from the device from the device so that it does not lose the effect of "novelty" associated with the extinction of the selective component of the libido [12].

We also trained animals to run from a box or a detachment on their own to a mechanical device, to make a garden and to go back (on a ring) before the start (table 1).

\section{1. . Training bulls for sperm injection in the technological line}

\begin{tabular}{|l|c|c|c|}
\hline \multicolumn{1}{|c|}{ Indicator } & \multicolumn{2}{c|}{ Unconstrained maintenance } & \multirow{2}{*}{ Difference } \\
\cline { 2 - 3 } & individual & group & \\
\hline $\begin{array}{l}\text { Distance from the initial line to the mechanical } \\
\text { installation, } m\end{array}$ & 70 & 15 & 55 \\
\hline $\begin{array}{l}\text { Number of repetitions spent on learning a bug } \\
\text { (average) }\end{array}$ & 4,0 & 3,1 & 0,9 \\
\hline $\begin{array}{l}\text { Spending time to overcome the distance in the } \\
\text { technological line, sec. }\end{array}$ & 138 & 204 & -66 \\
\hline
\end{tabular}

At the first stage, the bulls were trained on a technological line. The conduction ended with a "positive reinforcement" in the form of a garden and ejaculation on a mechanical device with inserted artificial vagina. At the second stage, the bulls themselves had a technological line and received "positive reinforcement".

Repetition of the interactions " ejaculation - opening of the exit" and with delay at the mechanical installation was "punishment - a weak electric shock "taught bulls" avoidance reaction", that is, to leave the playpen in his boxing or detachment shortly after sperm injection.

The components of sexual function in the bulls include: libido, erections, copulation and ejaculation. Libido bulls includes three functional components: energetic, selective and periodic [13].

Erection in the bulls, like libido, is also very sensitive to the effects of various injuries, common in the herd.

The copulation contains virtually all physiological systems of the organism, as fragments of a single behavior of bulls, of extraordinary biological significance. 
Ejaculation is also a complex reflex act that includes series components of the moving and excretory nature, which leads to a decrease in libido in bulls.

Violation of the prostatic-testicular interaction also leads to a deterioration of sexual function in the cats. It concludes that the prostate gland, which is an organ of the external secretion during the period of sexual reception, when its secret is not removed through the urethra, and absorbed and gets into the bloodstream, turns into an optional gland of the inner secretion.

In contrast to the direct spillage of the spermatic glands into the prostate gland, increased production of androgens in the bloodstream, which accelerates its anatomical development, has a reversible effect on the function of the spermatic glands. It enhances their activity during periods of elevated and holds back their tone during periods of reduced sexual activity of the pedigree. This disruption negatively affects sperm performance and puberty.

Studies have found that the deterioration of sexual activity and indicators of sperm in the bulls may be due to causes of non-specific Neutrogena origin associated with the initial signs of over-stress that can be overcome by stimulation.

To overcome the inhibition of sexual reflexes we were the first time express-stimulation of erogenous zones of cows was developed and applied by the method mechanical presses. Using a simple device, they pressed for 3-5 seconds. on the lumbosacral region (10-12 times), the area of the solar-eyed plexus (10-12 times for 5-7 seconds) and on the area of the anus and the interiors, which were treated with a spring-loaded pressure polyethylene head. The time interval between presses was 5-7 seconds.

The developed device was a $100 \mathrm{~mm}$ diameter disc with a metal handle The working elements of the device were polyethylene heads of spherical shape with a diameter of $12 \mathrm{~mm}$, which are fixed on a disk with a metal handle. We have also developed more effective prioritization devices for mechanopressure of erogenous acupuncture zones. With the help of the method of mechanopressure developed by us (table 2), for the first time, through erogenous acupunctural zones, we managed to irritate the nerve centers and obtain a full erection in the bulls before sperm collection, which positively influenced its volume and activity.

\section{The effectiveness of the mechanopressure of the reproductive system of the bulls}

\begin{tabular}{|l|c|c|c|c|}
\hline \multirow{2}{*}{ Indicator } & \multirow{2}{*}{\begin{tabular}{c} 
Number of bulls \\
\cline { 3 - 5 }
\end{tabular}} & $\begin{array}{c}\text { the volume } \\
\mathrm{ml}\end{array}$ & $\begin{array}{c}\text { activity, score } \\
\text { points }\end{array}$ & $\begin{array}{c}\text { concentration, } \\
\text { billion / ml.. }\end{array}$ \\
\hline By stimulation & 8 & 3,44 & 6,31 & 0,95 \\
\hline After stimulation & 8 & 4,94 & 7,63 & 1,04 \\
\hline Difference + & - & 1,50 & 1,30 & 0,09 \\
\hline
\end{tabular}

In connection with insufficient stability or disturbances of the components of the sex function, such as libido and erection, electrostimulation may be used to restore some of the sex-scale spheres to some clinically healthy cats.

The essence of this method is that the damped conductive fluid-based electrodes are localized in the position of "rectal-sacroil". At a frequency of modulation of $100 \mathrm{~Hz}$ and a depth of $100 \%$, the current slowly rises to the first signs of anxiety (threshold of pain sensitivity of animals). Then, the electrode fed 0.6 values of the individual threshold of pain sensitivity and influenced the indicated parts of the body of the pediatrician alternately with currents of 100 and $50 \mathrm{~Hz}$ at 1 st and 2 nd type of work for duration of 6 minutes. After that, the newly-wetted conductive fluid electrodes were localized in the position of the "testes-buttocks" and were influenced by a current of $35 \%$ of the threshold value of pain sensitivity in the 3rd and 2 nd types of works lasting 2 minutes. The general course of stimulation consisted of 3 procedures that were performed once a day. If needed, then the course of stimulation was repeated immediately, or as deterioration of the semen.

After electrostimulation, the sperm parameters improved in the boars of both groups (table 3 ). Thus, in the 1 st experimental group, the volume of ejaculate in the pedigrees was statistically significantly increased 
on average by $0.55 \mathrm{ml}$ and the concentration of sperm in the ejaculate increased by 689 million. The activity of the sperm increased significantly.

In the second group, the volume of ejaculate also increased by $0,56 \mathrm{ml}$. Almost 1 point increased the average activity of sperm, and the concentration increased by 50 million / $\mathrm{ml}$. The total number of sperm in the ejaculate increased by 578 million. The difference in sperm concentration was statistically highly reliable. The number of defective ejaculates in the boats of the 1 st experimental group decreased by $7.85 \%$ and the 2nd - by $4.95 \%$.

3. Indicators of sperm bumps with different threshold of pain sensitivity before and after electrostimulation,

\begin{tabular}{|l|c|c|}
\hline \multirow{2}{*}{ Indicator } & \multicolumn{2}{|c|}{ Groups } \\
\cline { 2 - 3 } & First & Second \\
\hline Threshold of pain sensitivity (mA) & $\frac{11}{3}$ & $\underline{20}$ \\
\hline The number of ejaculates studied & $\frac{47}{451}$ & $\frac{52}{364}$ \\
\hline Sperm Indicators: volume, ml & $\frac{1,7 \pm 0,12}{2,25 \pm 0,02}$ & $\frac{1,89 \pm 0,14}{2,45 \pm 0,07}$ \\
\hline activity, points & $\underline{8 \text { і вище }}$ & $\underline{8 \text { і вище }}$ \\
\hline Concentration, billion / ml. & $\underline{8 \text { і вище }}$ & $\frac{0,68 \pm 0,19}{0 \text { виее }}$ \\
\hline Total defective ejaculates, \% & $0,82 \pm 0,06$ & $0,81 \pm 0,001$ \\
\hline Total sperm count, billion $\%$ & $\frac{1,156}{1,845}$ & $\frac{1,406}{1,984}$ \\
\hline
\end{tabular}

Note: data in the numerator is given, and in the denominator - after electrostimulation

Thanks to the improvement of the semen of the bulls after electrostimulation of their sexual system, it was possible to freeze for 4.3 thousand granules a year. There were no cases of deterioration of sperm parameters in order to stabilize the health of bulls after electrostimulation. This accelerates the crude process [14].

\section{Conclusions}

1. Restrictions on intersexual selection in bulls receiving motions in ring corridors is possible by reducing the stress situation among fetuses due to the relative extinction of their libido on animals standing next to them. And its strengthening of those of which they are not in contact with the operation of the operation.

2. The dynamic stereotype of the wagon animal and the mechanical device is made by bulls on the basis of imprinting after the first withdrawal of sperm into an artificial vagina.

Bulls grown in conditions of group unbroken content, need to be accustomed to the impact of sperm by the group mediated method on individuals who are not in their group, using their ability to learning complex forms of behavior, according to the principle of conditioned reflex.

3. The developed original method and devices for the mechanic-pressurization of erogenous acupuncture zones allow to restore the functioning of the energy component of the libido and full erection in the bulls, which positively affects the volume of ejaculate and the activity (mobility) of the spermatozoa of the fetuses.

4. A safe priority method and devices for conducting electrostimulation of the reproductive system of cows with sinusoidal modulated currents (SMS), which is based on the individual approach to each animal and taken into account the threshold of its pain sensitivity, is accompanied by the improvement of semen of the pedigrees. 
5. Contrasting differences in the methods of limiting the effect of intersexual selection most clearly revealed in the 18-month age of animals, when bulls the experimental group (non-binding retention) was inferior to the control counterparts (attachment retention) for a live weight of $50 \mathrm{~kg}(P<0,1)$, the total number of sperm in the ejaculate - the bulls of the control group surpassed the homegrown bulls of the experimental group by 34.2 and subordinates to $79.7 \%$.

6. Restoration of gas exchange after sexual tension to the initial. The level in the control group bulls (tethered retention) was completed in the course of the day, and in animals from the experimental group (non-contact retention) - after 3-4 hours. The study of gas exchange made it possible for the first time to observe the phenomenon of elevated oxygenation of the bull's organism during sexual excitement and ejaculation.

7. For the first time, the regularity of the inadequate response of the response of the bulls grown on the leash, or the restriction of the intersexual selection to external stimuli, which became the main cause of their active-defensive and violent behavior caused by the balancing and inhibitory phases of the activity of the cerebral cortex. Restoration of reactions to stimuli to norm was observed in bulls only after their transfer to group unconstrained maintenance and establishment of the hierarchy.

8. Objective assessment of the type of higher nervous activity (VND) and the type of constitution in the shvets breed bogs made it possible for the first time to establish that $63.9 \%$ of strong types of GNI belong to widespread and $36.1 \%$ to narrow-minded types of constitution, which greatly simplifies selection of animals of the desired type for evaluation and use in breeding.

9. After artificially induced stress, at administration of adrenocorticotropic hormone (ACTH) to boils, a statistically significant decrease in sperm activity was observed at $50.0 \%(P<0.05)$ regardless of the type of their nervous system.

\section{Bibliography}

1. Durova-Sadovskaya A.V. (1965). K voprosu o vospitanii napravlennogo povedeniya zhivotnyh v selskom hozyajstve. Biol. osnovy podrazhatelnoj deyatelnosti i stadnyh form povedeniya. [On the issue of raising the direction of animal behavior in agriculture. Biol the basis of imitative activity and herd forms of behavior]. Moskva - Leningrad. P. 27 - 30. [in Russian].

2. Zubets M.V. (2010). Etolohiia molochnoi khudoby: navchalne ta navchalno-metodychne vydannia. [The ethology of dairy cattle: educational and educational-methodical edition]. Kharkiv: View of Brovi O.V. $264 \mathrm{p}$. [in Ukrainian].

3. Lebedev M.M. (1979). Nauka o povedenii zhivotnyh i aktualnye zadachi industrialnogo zhivotnovodstva. [The science of animal behavior and actual problems of industrial livestock breeding]. Behavior of animals in conditions of industrial complexes. Moscow: Kolos. P. 5-14. [in Russian].

4. Pushkarsky V.G. (1974). Modelirovannoe povedenie s.-h. zhivotnyh v promyshlennyh kompleksah. [Simulated behavior of c.-h. animals in industrial complexes]. Vestnik selskohozyajstvennoj nauki. No. 4. P. 85-91. [in Russian].

5. Serytskyy Y.S. (2015). Metody otsinky vidtvoriuvalnoi zdatnosti khudoby. [Methods for assessing the reproductive capacity of livestock]. Kiev: Ahrarna nauka. Pp. 175-178. [in Ukrainian].

6. Fedorovych V.V. (2007). Formuvannia vidtvornoi zdatnosti buhaiv-plidnykiv chorno-riaboi khudoby Ukrainy. [Formation of reproductive capacity of bulls-breeders of black-and-white cattle of Ukraine]. Kyiv: LluKSAR. 193 p. [in Ukrainian].

7. Oliynyk S.O. (2002). Etolohichni osoblyvosti utrymannia buhaitsiv riznykh henotypiv. [The ethological features of the maintenance of Bugites of different genotypes]. Visnyk Dnipropetrovskoho ahrarnoho universytetu. № 2. P. 131 - 132. [in Ukrainian].

8. Artemova O. (2007). Humanizm yak skladova yakosti tvarynnytskoi produktsii. [Humanism as a component of the quality of livestock products ]. Kyiv: Meha-Polihraf. C. 1-3. [in Ukrainian].

9. Kruhliak P.A. (2006). Spermoproduktyvnist buhaiv-polipshuvachiv, yaki tryvalyi chas ne vykorystovuvalys. [First-rate productivity of bull-enhancers, which for a long time were not used]. Problemy rozvytku tvarynnytstva. V. 2. P. 68-69. [in Ukrainian].

10. Nadtochii V.M. (2005). Vikovi ta porodni zminy pokaznykiv spermoproduktyvnosti buhaiv. [Age and genetic changes in the indices of bull sperm production. Rose-keeping and animal genetics]. Rozvedennia $i$ henetyka tvaryn. V. 39. P. 145 - 148. [in Ukrainian]. 
11. Karpova O. (2004). Adaptivnye principy vedeniya skotovodstva v Povolzhe. [Adaptive principles of cattle breeding in the Volga region. Dairy and meat cattle breeding ]. Molochnoe i myasnoe skotovodstvo. № 8. P. 7-8. [in Russian].

12. Koropets $L$. (2002). Uspadkuvannia i povtoriuvanist pokaznykiv symentalskoi porody. [Inheritance and repeatability of the Simmental breed indicators]. Tvarynnytstvo Ukrainy. 2002. № 2. P. 23. [in Ukrainian].

13. Mironchik E.A. (2008). Etologicheskie aspekty proizvodstva produktov zhivotnovodstva. [Ethological aspects of production of livestock products]. Efektivne tvarinnictvo. № 8. P. 42-44. [in Russian].

14. Denysiuk O.V. (2009). Rol otsinenykh buhaiv u porodotvornomu protsesi. [The role of evaluated bulls in the rooting process]. Visn. Instytutu tvarynnytstva tsentralnykh raioniv UAAN. Dnipropetrovsk: Delita. P. 198 - 218. [in Ukrainian]. 